\title{
Monitoring inbreeding trends and inbreeding depression for economically important traits of Holstein cattle in Iran
}

\author{
M. Rokouei, ${ }^{\star}$ R. Vaez Torshizi, ${ }^{1}{ }^{1}$ M. Moradi Shahrbabak, $†$ M. Sargolzaei,‡ and A. C. Sørensen§ \\ *Department of Animal Science, Tarbiat Modares University, Tehran, Iran \\ †Department of Animal Science, University of Tehran, Karaj, Iran \\ ¥Centre for Genetic Improvement of Livestock, University of Guelph, Guelph, Ontario, Canada \\ §Department of Genetics and Biotechnology, Aarhus University, Denmark
}

\begin{abstract}
Pedigree information of 852,443 registered Holstein cows and bulls, collected by the Animal Breeding Center of Iran from 1971 to 2007, was used to calculate inbreeding coefficients and their effect on production, reproduction, somatic cell count, calving ease, and longevity traits. The average inbreeding coefficient for the entire population was $2.90 \%$, ranging from zero to $47.03 \%$. The rates of inbreeding from 1989 to 2007 were 0.22 and $0.15 \%$ per year for females and males, respectively. The rates were higher after 2000, being 0.31 and $0.21 \%$ per year for females and males, respectively. Inbreeding had a deleterious effect on most traits. For the first 3 lactations, the inbreeding depression per $1 \%$ increase in inbreeding was $-18.72,-16.19$, and $-27.38 \mathrm{~kg}$ for milk yield, $-0.443,-0.367$, and -0.690 $\mathrm{kg}$ for fat yield, and $-0.476,-0.425$, and $-0.66 \mathrm{~kg}$ for protein yield, respectively. For all reproductive traits, the observed undesirable effect of inbreeding was not significant, except for the calving interval $(0.53 \mathrm{~d}$ per $1 \%$ increase in inbreeding) in the third parity and age at first calving ( $0.45 \mathrm{~d}$ per $1 \%$ increase in inbreeding). Calving ease in heifers and cows was significantly influenced by the inbreeding of the dam, indicating that highly inbred cows had a higher incidence of difficult calvings. The estimate of inbreeding depression for somatic cell score was low and significant only for the third lactation. However, animals with high inbreeding coefficient tended to have higher somatic cell scores than animals with low inbreeding coefficients. For type traits, the influence of inbreeding was significant only for stature, chest width, body depth, size, rear udder height, suspensory ligament, udder depth, and front and rear teat placement. Cows with high levels of inbreeding coefficient were at higher relative risk of being culled.
\end{abstract}

Received September 18, 2009.

Accepted February 2, 2010.

${ }^{1}$ Corresponding author: rasoult@modares.ac.ir
Key words: inbreeding depression, production, reproduction, Iranian Holstein

\section{INTRODUCTION}

The increasing rate of application of AI during the past few decades has resulted in widespread use of only a few top sires. The best animals accumulate in pedigrees so that today it is practically impossible in a given dairy cattle breed to find animals without multiple genetic ties to certain individuals (Croquet et al., 2006). Thus, the probability of mating relatives and generating inbred offspring is increased. The rate of increase in inbreeding coefficient has been reported for Holstein dairy cattle populations in the United States (Wiggans et al., 1995; Thompson et al., 2000), Canada (Miglior and Burnside, 1995), the United Kingdom (Kearney et al., 2004), Denmark (Sørensen et al., 2005), and Ireland (Mc Parland et al., 2007). The detrimental effect of inbreeding on important traits in dairy cattle has been well documented by several studies. In spite of the difference in magnitude, inbreeding depression decreases milk production traits and survival (Thompson et al., 2000) and SCS (Sørensen et al., 2006) and increases calving interval and age at first calving (Mc Parland et al., 2007) and dystocia (Adamec et al., 2006; GonzálezRecio et al., 2007). For linear type traits, the effect of inbreeding was reported to be relatively small (Croquet et al., 2006).

In recent years, levels and trends of inbreeding for the Holstein population in Iran have been studied. Average inbreeding coefficients of $0.18 \%$ in 1999 (Tohidi et al., 2002) and 1.33\% in 2007 (Faraji Arogh, 2009) have been reported. Consequently, the perception is that inbreeding in the Holstein population in Iran is under control, although there is no ongoing mating strategy to control inbreeding. However, considering the widespread use of a few North American and European proven sires in Iran, one would expect higher levels of inbreeding. One possible explanation for the low level of inbreeding is incomplete pedigrees. Pedigree information related to imported semen is limited and goes back only to grand- 
parents in most cases. All previous studies on Iran Holstein cattle were based on pedigrees with a relatively high degree of incompleteness, especially for foreign sires. In addition, inbreeding depression has been estimated without considering pedigree completeness. This is likely to cause bias in estimates of inbreeding trend and inbreeding depression.

Therefore, the objectives of this study were 1) to assess the rate and level of inbreeding in the Holstein population of Iran using more complete pedigrees; and 2 ) to estimate inbreeding depression for production, reproduction, SCS, calving ease, type, and longevity traits in the first 3 lactations.

\section{MATERIALS AND METHODS}

\section{Pedigree Information and Inbreeding}

Pedigree information of 852,443 registered Holstein cows and bulls, collected by the Animal Breeding Center of Iran (ABCI, Karaj, Iran) from 1971 to 2007, was used in this study. Also, all available information of the pedigree from 1,419 international sires (born from 1971 to 2003) with relatives in Iran was obtained from Canadian Dairy Network (Guelph, Ontario, Canada) and the Interbull Center (Uppsala, Sweden) as far back as possible, and all ancestors (34,899 animals) were added to the original pedigree for creating a more complete pedigree. This pedigree was used to calculate the pedigree completeness based on MacCluer et al. (1983) and the inbreeding coefficients for each animal using the EVA software (Berg et al., 2006).

For this pedigree, a reference population, namely the calves born in Iran from 2002 to 2007 with a minimum pedigree completeness of 0.7 for 5 generations, was defined (Sørensen et al., 2005). The reference population was chosen as a group of animals representing the live animals. Therefore, 6 years of birth cohorts were chosen, and pedigree of these animals was traced back. This excluded older animals without descendants in the live population. These animals are not informative to estimate the rate of inbreeding in the population of animals today. The reference population contained 251,697 animals with average pedigree completeness of 0.93 . For reference animals, the available pedigree was traced back to the founders. Animals with unknown parents were considered as founders. The pedigree of the reference population contained 507,673 animals with 35,877 founders. Because the average birth date for the founders in the original pedigree was 1989, this year was considered the base year. In the pedigree file, 96.3 and $3.7 \%$ of animals were female and male, respectively. In addition, $92.9,91.7$, and $90.4 \%$ of all animals had known sire, known dam, and known sire and dam, respectively. The trend of inbreeding was calculated based on the regression coefficient of inbreeding per year.

\section{Performance Data}

Data on production, reproduction, SCC, calving ease, and longevity traits, collected during 1991 to 2007, were obtained from the ABCI. For all traits, the records of animals with a minimum pedigree completeness of 0.7 for 5 generations back were kept. The average completeness of pedigree for all animals with records was $>0.90$. In general, the data were limited to the first, second, and third parities.

For production traits, milk yield (MY), fat yield $(\mathbf{F Y})$, and protein yield (PY) were considered. These traits were standardized on a 305-d and twice-dailymilking basis. Only animals with age from 20 to 40 mo at the first calving were included. All animals with lactations $\geq 305 \mathrm{~d}$ were kept in the analysis.

Reproduction traits, which were defined based on data availability of the reproductive history recorded on each cow, were days from first service to conception (FSTC), gestation length (GL), age at first calving (AFC), days from calving to first insemination (CFI), calving interval (CI), and calving ease $(\mathbf{C E})$ as a trait of the calf. To determine the conception date, which was used to create FSTC and GL, the subsequent calving date that agreed with the latest insemination date was used. Thus, only cows that had a subsequent calving were kept. Gestation length was measured as an interval from the last insemination to the subsequent calving. The CFI was defined as an interval from calving to first insemination and was limited to the first and second parities. These definitions for reproductive traits have been made based on the descriptions provided by Jamrozik et al. (2005). Calving ease was subjectively scored in 5 classes $(1=$ no problem, $2=$ slight problem, $3=$ needed assistance, $4=$ considerable force, and $5=$ extreme difficulty). Records from multiple births and calves resulting from abortions were omitted from the data.

For SCS, data consisted of 968,884 test-day records from 94,181 cows. The SCS were computed from SCC, using the formula presented by Ali and Shook (1980): $\mathrm{SCS}=\left[\log _{2}(\mathrm{SCC} / 100,000)\right]$. For SCS, data with DIM from 5 to $305 \mathrm{~d}$ and age at calving from 20 to $40 \mathrm{mo}$ in the first parity were considered. Details of the number of records, means, and standard deviations for production traits, reproduction traits, and SCS, and their corresponding inbreeding coefficients in each parity are presented in Table 1.

The data for the first 3 parities of the type traits were collected on 35,277 cows by ABCI during 1994 and 
Table 1. Summary of the data structures for production and reproduction traits, calving ease, and SCS for first, second, and third parities

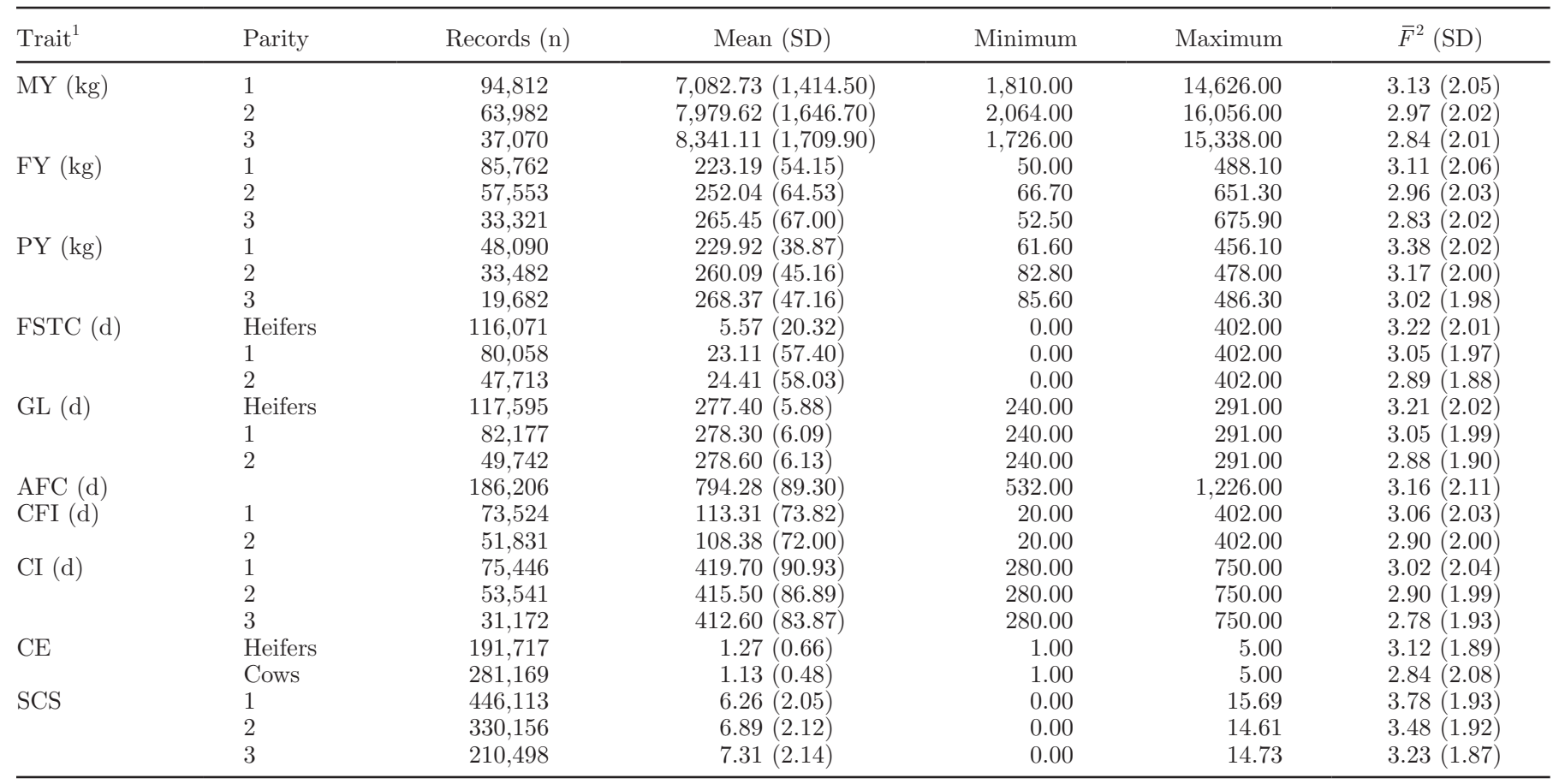

${ }^{1} \mathrm{MY}=$ milk yield $305-\mathrm{d} ; \mathrm{FY}=$ fat yield 305 -d; PY = protein yield 305 -d; FSTC = interval from first service to conception; $\mathrm{GL}=$ gestation length; $\mathrm{AFC}=$ age at first calving; $\mathrm{CFI}=$ interval from calving to first insemination; $\mathrm{CI}=$ calving interval; $\mathrm{CE}=\mathrm{calving}$ ease $(1=\mathrm{no}$ problem, $5=$ extreme difficulty).

${ }^{2} \bar{F}=$ average inbreeding coefficient of animals with records.

2007. A linear appraisal scoring from 1 to 9 were applied to most records based on the system presented by the Holstein Association of Canada, except for stature, size, rump length, pin width, rear udder height, and rear udder width, which were measured objectively. For stature, size, rump length, pin width, rear udder height, rear udder width, ranges of 120-166 cm, 150-245 cm, 40-68 cm, 15-28 cm, 15-45 cm, and 6-30 cm, respectively, were considered. Description of the linear type traits is presented in Table 2 .

Longevity was defined as the number of days from first calving to culling, death, or censoring date. Records associated with incorrect calving date, calving interval outside the range of 280 to $750 \mathrm{~d}$, and age at first calving outside 20 to 40 mo were excluded from the data. A lifetime record was considered completed (uncensored) if the cow received a termination code, indicating that she was culled or died for any reason. Censored records represented cows being sold, leased to other herds, or still in the herd. There was a positive correlation between inbreeding coefficient and censoring of records initiated after 2002 because of the increased number of cows still alive, and therefore censored, when data collection was terminated. These cows also had the highest average inbreeding. Therefore, only records from 1991 to 2002 were kept for analysis to avoid the spurious correlation between inbreeding as an explanatory variable and censoring. Table 3 indicates more details for the longevity data set.

\section{Models}

Because of the analysis of a wide range of traits and differences in their fixed and random effects, various animal models were applied. Considering each lactation record as a different trait, a multivariate animal model [1] was fitted to the production and some reproduction traits. For calving ease and linear type traits, a singletrait animal model [2] and a repeated-record animal model [3] were fitted, respectively. The statistical forms of each model were as follows:

$$
\begin{array}{cl}
y_{i j k}=\mu_{i}+H Y S_{i j}+\beta_{i 1} A G E_{i k}+\beta_{i 2} F_{k}+a_{i k}+e_{i j k}, & {[1]} \\
y_{j k l m n}=\mu+ & H Y S_{j}+S E X_{k}+\beta_{1} A G E_{m}+\beta_{2} F M_{m} \\
+ & \beta_{3} F_{n}+a_{n}+m_{n}+e_{j k l m n}, \\
y_{j k m n}=\mu+H Y_{j} & +L S_{k}+\beta_{1} A G E_{m}+\beta_{2} F_{m} \\
& +a_{m}+p_{m}+e_{j k m n},
\end{array}
$$


Table 2. Summary of the data structures for type traits

\begin{tabular}{lcr}
\hline Trait $^{1}$ & Records (n) & Mean (SD) \\
\hline Stature (cm) & 35,277 & $141.79(3.77)$ \\
Chest width & 35,243 & $5.79(1.20)$ \\
Body depth & 35,163 & $5.91(1.12)$ \\
Loin & 35,214 & $6.26(1.18)$ \\
Size $(\mathrm{cm})$ & 35,277 & $197.94(8.84)$ \\
Rump length $(\mathrm{cm})$ & 35,277 & $52.39(2.35)$ \\
Pin set & 35,277 & $2.42(1.79)$ \\
Pin width (cm) & 35,277 & $20.19(1.79)$ \\
Rear leg side view & 35,239 & $5.54(0.96)$ \\
Foot angle & 35,248 & $5.08(1.15)$ \\
Fore udder attachment & 35,231 & $6.20(1.68)$ \\
Rear udder height (cm) & 35,277 & $26.38(2.65)$ \\
Rear udder width $(\mathrm{cm})$ & 35,277 & $17.21(2.57)$ \\
Suspensory ligament & 35,259 & $5.82(2.04)$ \\
Udder depth & 35,243 & $4.87(1.54)$ \\
Front teat placement & 35,241 & $4.87(1.10)$ \\
Rear teat placement & 35,244 & $5.95(1.40)$ \\
Teat length & 35,173 & $4.98(0.96)$ \\
Angularity & 35,131 & $6.92(0.87)$ \\
\hline${ }^{1}$ A linear appraisal scoring from 1 to 9 were applied to most records based on the system presented by the \\
Holstein Association of Canada, except for stature, size, rump length, pin width, rear udder height, and rear \\
udder width, which were measured objectively.
\end{tabular}

where $y_{i j k}$ is the record of animal $k$ in parity $i(i=1,2,3)$ for traits MY, FY, PY, FSTC, GL, CFI, and CI; $\mu_{i}$ is the overall mean for each parity; $H Y S_{i j}$ is the effect of herd-year-season at calving; $A G E_{i k}$ is the effect of age at calving; $\beta_{i 1}$ is the regression coefficient on age at calving; $F_{k}$ is individual inbreeding coefficient; $\beta_{i 2}$ is the regression coefficient on individual inbreeding; and $a_{i k}$ and $e_{i j k}$ are random direct additive genetic and residual effects. A random service sire effect was fitted for FSTC and GL. For the CFI, a fixed effect of herdyear-month of last calving was fitted instead of HYS (Andersen-Ranberg et al., 2005). Also, for this trait, only the first 2 parities were included in the analysis. Age at first calving was analyzed univariately using the same model by excluding AGE from the model.

In model $2, y_{j k l m n}$ is the calving ease of calf $k$ born by heifers $n ; \mu$ is the overall mean; $H Y S_{j}$ is the effect of herd-year-season; $S E X_{k}$ is the effect of sex; $\beta_{1}, \beta_{2}$, and $\beta_{3}$ are regression coefficients on age at calving $\left(A G E_{m}\right)$, inbreeding of the dam $\left(F M_{m}\right)$, and calf $\left(F_{n}\right)$, respectively; and $a_{n}, m_{n}$, and $e_{j k l m n}$ are random direct additive genetic, maternal additive genetic, and residual effects, respectively. A nonzero direct and maternal additive genetic covariance was assumed. For calves produced from the second to fourth parities, a similar model was used except that a fixed effect of parity and a random effect of permanent environmental effect due to the dam were included.

In model $3, y_{j k m n}$ is a repeated record from the first 3 parities of 19 linear type traits; $\mu$ is the overall mean; $H Y_{j}$ is the effect of herd-year of calving; $L S_{k}$ is the effect of lactation stage (4 classes: $<30,30$ to 60,60 to 120 , and $>120 \mathrm{DIM}) ; \beta_{1}$ and $\beta_{2}$ are the regression coefficients on age at calving $\left(A G E_{m}\right)$ and individual inbreeding coefficient $\left(F_{m}\right)$, respectively; and $a_{m}, p_{m}$, and $e_{j k m n}$ are random direct additive genetic, permanent environment due to the animal, and residual effects.

For SCS, the following multi-lactation random regression test-day model was used:

$$
\begin{aligned}
y_{i j k l m n o p} & =\mu+M T_{i}+H T M_{j}+L_{k}+\beta_{1} A G E_{l}\left(L_{k}\right)+\beta_{2} F_{m}\left(L_{k}\right) \\
& +\sum_{p=0}^{3} D_{q} X_{p q}+\sum_{p=0}^{3} U_{o p q} X_{p q}+\sum_{p=0}^{3} P_{o p q} X_{p q}+e_{i j k l m n o p},
\end{aligned}
$$

where $y_{i j k l m n o p}$ is SCS; $\mu$ is the overall mean; $M T_{i}$ is the effect of number of daily milkings (2 or 3 times); $H T M_{j}$ is the effect of the interaction between herd and month of test; $L_{k}$ is the effect of lactation (the first 3 parities); $\beta_{1}$ is the regression coefficient on $A G E_{l}$ within

Table 3. Summary of data structure for longevity

\begin{tabular}{lc}
\hline Cows (n) & 146,438 \\
Herds (n) & 1,250 \\
Right-censored records (\%) & 24.80 \\
Average inbreeding coefficient for censored records & 3.07 \\
Time from first calving until censoring (d) & 1 \\
Minimum & 1,409 \\
Average & 4,577 \\
Maximum & 2.76 \\
Average inbreeding coefficient for complete records & 1 \\
Time from first calving until culling (d) & 988 \\
Minimum & 4,922 \\
Average & \\
Maximum & \\
\hline
\end{tabular}


parity; $\beta_{2}$ is the regression coefficient on individual $F_{m}$ within parity; $D_{q}$ is a fixed regression on $X_{p q}$, which is the $p$ th order of Legendre polynomial (third order) corresponding to DIM on the qth test-day; $U_{o p q}$ is a random genetic regression for animal $o ; P_{o p q}$ is a random permanent environmental regression for animal $o$; and $e_{i j k l m n o p}$ is residual effect, assumed to have the same variance within each parity.

For longevity, the Weibull proportional hazard model (Ducrocq and Sölkner, 1998a) was as follows:

$$
\begin{aligned}
h_{i j k l m n o}(t) & =h_{0}(t) \exp \left[\text { hys }_{i}(t)+h_{\mathrm{var} j}(t)+p_{k}\left(t_{1}, t_{2}\right)\right. \\
& \left.+m_{l}(t)+\beta_{1} A F C_{m}+F_{n}+s_{o}\right],
\end{aligned}
$$

where $h_{i j k l m n o}(t)$ is the hazard function of a given cow at time $t ; h_{0}(t)$ is the Weibull baseline hazard function with scale parameter $\lambda$ and shape parameter $\rho, h_{0}=\lambda \rho$ $(\lambda t)^{\rho-1} ; h y s_{i}(t)$ is the time-dependent random effect of herd-year-season, assumed to be independently distributed, following a log-gamma distribution; $h_{\mathrm{var} j}(t)$ is the fixed time-dependent class effect of change in herd size (5 classes: changes $\leq-5 \%,-5 \%<$ change $\leq 5 \%, 5 \%$ $<$ change $\leq 15 \%, 15 \%<$ change $\leq 35 \%$ and changes $>$ $35 \%) ; p_{k}\left(t_{1}, t_{2}\right)$ is a time-dependent combined effect of lactation number (lactation 1 to $6+$ ) and stage of lactation, $t_{1}$ days after first calving and $t_{2}$ days after current calving with changes at 270 and $380 \mathrm{~d}$ of each parity. The lactation value changed at the beginning of a new lactation. The $m_{l}(t)$ is the fixed time-dependent effect of within herd-year class of 305-d mature-equivalent milk production. The effect of within-herd production was included to account for voluntary culling based on milk production. Five classes of milk production were considered: less than $-1.5 \mathrm{SD}$, between -1.5 and -0.5 $\mathrm{SD}$, between -0.5 and $0.5 \mathrm{SD}$, between 0.5 and $1.5 \mathrm{SD}$, and greater than $1.5 \mathrm{SD}$ with changes at the beginning of a new lactation. Cows without standard lactation records in the current lactation were assigned to the same production class as in their previous lactation. The $\beta_{1}$ is the time-independent regression on $A F C_{m}$, which is the age at first calving; $F_{n}$ is the time-independent effect of inbreeding as a discrete variable with 5 classes: $F<3.125 \%, 3.125 \% \leq F<6.250 \%, 6.250 \% \leq$ $F<12.500 \%, 12.500 \% \leq F<18.750 \%$, and $F \geq$ $18.750 \%$; and $s_{o}$ is a time-independent random effect of sire, assumed to be distributed as multivariate normal with mean vector 0 and covariance matrix $\mathbf{A} \sigma_{s}^{2}$, where $\mathbf{A}$ is the additive genetic relationship matrix and $\sigma_{s}^{2}$ is the additive genetic variance of sires. The variance components for hys and sire were estimated one at a time and fixed while estimating the other until no changes were observed between consecutive iterations. The DMU package (Madsen and Jensen, 2007) was used to carry out all analyses except for the analysis of longevity. For longevity traits, Survival Kit version 3.12 (Ducrocq and Sölkner, 1998b) was used.

\section{RESULTS AND DISCUSSION}

The descriptive statistics for inbreeding coefficient of the pedigree of reference population for animals born between 1989 and 2007 are presented in Table 4. The rate of inbreeding estimates from 1971 to 1989 was close to zero $(0.014$ and $-0.016 \% / y r$ for males and females, respectively); therefore, the average inbreeding coefficients since 1989 was reported. In general, the average inbreeding coefficient of $2.90 \%$ for the entire population and $3.45 \%$ for the inbred population were higher than the corresponding estimates of 0.18 and $2.18 \%$, and 0.76 and $1.96 \%$ reported by Tohidi et al. (2002) and Faraji Arogh (2009), respectively. This increase in inbreeding in the current study is likely because of the more complete pedigree structure. The average pedigree completeness within each year for the original and complete pedigrees is shown in Figure 1. The higher average pedigree completeness of 0.97 and 0.94 for male and female populations in the relatively complete pedigree for 2007, compared with 0.78 and 0.78 in the original pedigree, clearly resulted in less biased estimates of inbreeding. A similar reduction in the average inbreeding coefficients due to the partial pedigrees was reported in the study of Cassell et al. (2003).

Average inbreeding coefficients by year of birth of all animals born between 1989 and 2007 are shown in

Table 4. Average inbreeding coefficient (\%) between 1989 and 2007 for Iran Holstein population

\begin{tabular}{lrccc}
\hline Population & Animals $(\mathrm{n})$ & Mean (SD) & Minimum & Maximum \\
\hline Entire & & & & \\
Male + female & 455,847 & $2.90(2.43)$ & 0.00 & 47.03 \\
Male & 8,442 & $3.95(2.55)$ & 0.00 & 35.01 \\
Female & 447,405 & $2.88(2.42)$ & 0.00 & 47.03 \\
Inbred & & & & 47.03 \\
$\quad$ Male + female & 383,343 & $3.45(2.26)$ & 0.03 & 35.01 \\
Male & 8,094 & $4.12(2.47)$ & 0.07 & 47.03 \\
Female & 375,249 & $3.44(2.25)$ & 0.03 & \\
\hline
\end{tabular}




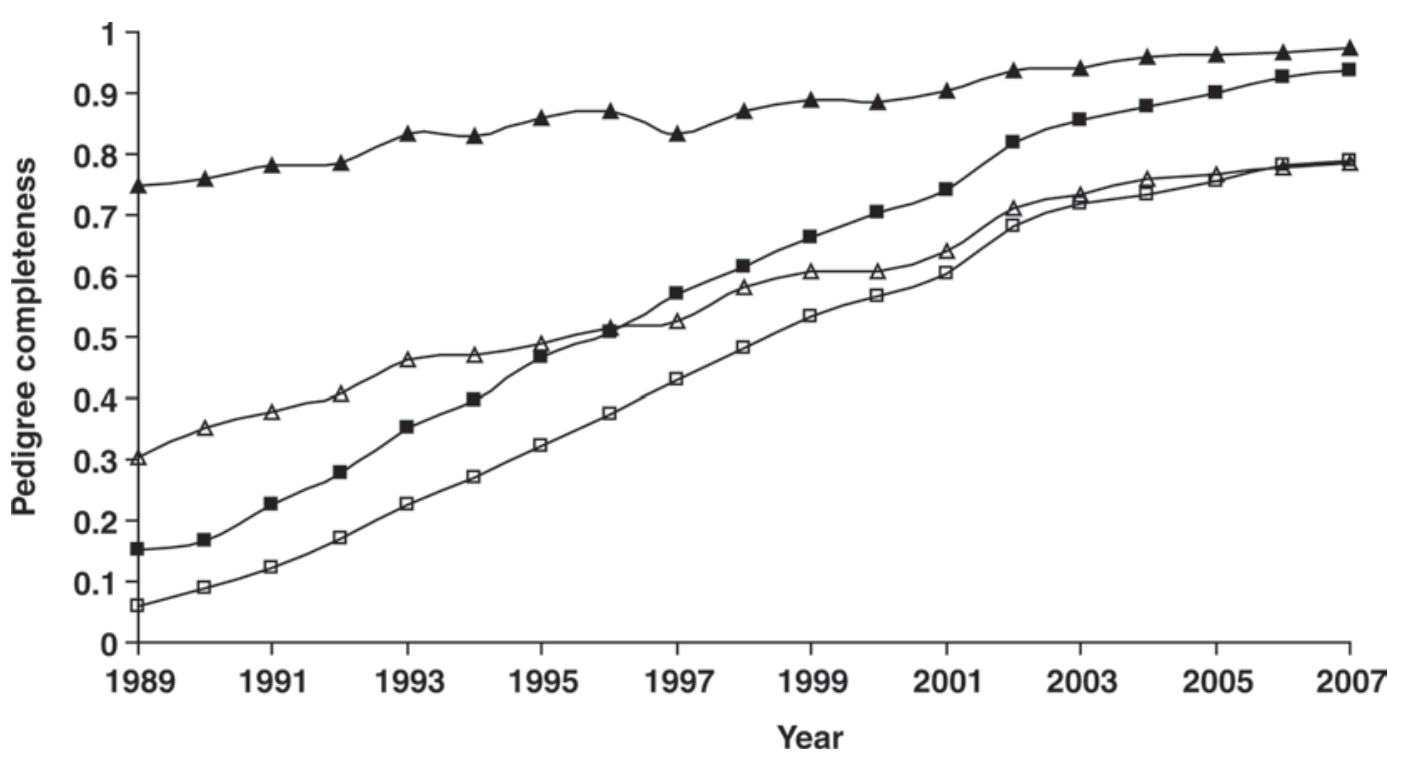

Figure 1. Average pedigree completeness over 5 generations within year of birth for males $(\Delta)$ and females $(\square)$ in original pedigree and males $(\boldsymbol{\Lambda})$ and females (ם) in complete pedigree.

Figure 2. The rate of inbreeding increased by 0.22 and $0.15 \%$ per year (with a generation interval of almost 6 yr, 1.32 and $0.90 \%$ per generation) and ultimately approached 4.40 and $5.23 \%$ in 2007 for females and males, respectively. The increase was substantially higher in recent years $(0.31$ and $0.21 \%$ per year in females and males from 2000 to 2007, respectively) compared with the decade from 1990 to 2000 (0.17 and $0.15 \%$ per year in females and males, respectively). In spite of the fact that the estimate of inbreeding coefficient for the Iranian Holstein cows was lower than the corresponding estimates of 5.33 and $5.75 \%$ reported for US (Animal Improvement Programs Laboratory, 2009) and Canadian (Canadian Dairy Network, 2009) Holsteins in 2007, the rate of inbreeding from 2000 to 2007 in the current study $(0.31 \%$ per year) was considerably higher than the values for the United States $(0.11 \%$ per year $)$ and Canada ( $0.08 \%$ per year). These discrepancies are because of the use of a few proven sires in Iran and may indicate the lack of an ongoing mating strategy to control inbreeding.

Estimates of inbreeding depression for production traits, reproduction traits, and SCS are presented in Table 5. Inbreeding significantly reduced $(P<0.01)$ milk production traits by 16.20 to $27.40 \mathrm{~kg}$ of MY, 0.37 to $0.69 \mathrm{~kg}$ of $\mathrm{FY}$, and 0.43 to $0.67 \mathrm{~kg}$ of PY in different lactations for each $1 \%$ increase in inbreeding. These estimates were higher than the previous results reported by Tohidi et al. (2002) on milk yield $(-12.45$ $\mathrm{kg})$ and fat yield $(-0.39 \mathrm{~kg})$ due to higher estimate of inbreeding for each animal. A relatively similar result has been reported for milk and protein yields $(-18.81$ and $-0.65 \mathrm{~kg}$ per $1 \%$ increasing in inbreeding for the first lactation) by Croquet et al. (2006) in Belgian Holsteins. For US Holsteins, the reduction was reported to be much higher: $-37.23,-1.36$, and $-1.36 \mathrm{~kg}$ for milk, fat and protein yields, respectively (Cassell, 2009). Falconer and Mackay (1996) stated that greater inbreeding depression results from a rapid increase in inbreeding. Therefore, more milk production losses were expected in the Iran Holstein population because of the higher rate of inbreeding. This disagreement may be attributed to the lower average milk production level of Iranian Holsteins $(7,083 \mathrm{~kg})$ compared with US Holsteins $(12,054$ kg; Animal Improvement Programs Laboratory, 2009).

Inbreeding did not have any significant deleterious effect on reproduction traits, except for CI in the third lactation and AFC, which were increased by 0.53 and $0.45 \mathrm{~d}$, respectively, for each $1 \%$ increase in inbreeding. These results are in agreement with the findings of $\mathrm{Mc}$ Parland et al. (2007) who reported $0.70 \mathrm{~d}$ longer calving interval and $0.20 \mathrm{~d}$ higher age at first calving per $1 \%$ increase in inbreeding in Irish Holstein-Friesians. For CE, accounting for inbreeding of the dam resulted in undesirable increases $(P<0.01)$ in calving ease score $\left(6.59 \times 10^{-3}\right.$ for heifers and $5.79 \times 10^{-3}$ for cows $)$. The lower inbreeding depression of cows compared with heifers on CE suggested that difficult calvings are much more common in first-calf heifers than in older cows. The inbreeding effect of the calf on $\mathrm{CE}$ was negative $\left(-2.09 \times 10^{-3}\right)$ and significant $(P<0.01)$ only in heifer calvings. This desirable effect of inbreeding depression indicates that the inbred calves were born more easily, presumably because they were smaller than less inbred calves. By treating inbreeding as a class variable, Mc Parland et al. (2007) reported that dams with inbreed- 
Table 5. Estimates of inbreeding depression and SE for $1 \%$ increase of inbreeding and their corresponding $P$-value for production and reproduction traits, calving ease (units $\times 10^{-3}$ ), and SCS (units $\times 10^{-3}$ ) for first, second, and third parities

\begin{tabular}{|c|c|c|c|}
\hline Trait $^{1}$ & Parity & Inbreeding depression $^{2}(\mathrm{SE})$ & $P$-value \\
\hline \multirow[t]{3}{*}{ MY (kg) } & 1 & $-18.70(2.04)$ & $<0.001$ \\
\hline & 2 & $-16.20(2.90)$ & $<0.001$ \\
\hline & 3 & $-27.40(4.18)$ & $<0.001$ \\
\hline \multirow[t]{3}{*}{ FY (kg) } & 1 & $-0.44(0.07)$ & $<0.001$ \\
\hline & 2 & $-0.37(0.10)$ & $<0.001$ \\
\hline & 3 & $-0.69(0.15)$ & $<0.001$ \\
\hline \multirow[t]{3}{*}{ PY $(\mathrm{kg})$} & 1 & $-0.48(0.08)$ & $<0.001$ \\
\hline & 2 & $-0.43(0.12)$ & $<0.001$ \\
\hline & 3 & $-0.67(0.17)$ & $<0.001$ \\
\hline \multirow[t]{3}{*}{ FSTC (d) } & Heifers & $-0.01(0.03)$ & 0.408 \\
\hline & 1 & $0.16(0.10)$ & 0.051 \\
\hline & 2 & $0.16(0.14)$ & 0.125 \\
\hline \multirow[t]{3}{*}{ GL $(d)$} & Heifers & $0.01(0.01)$ & 0.184 \\
\hline & 1 & $0.01(0.01)$ & 0.274 \\
\hline & 2 & $-0.01(0.02)$ & 0.363 \\
\hline $\operatorname{AFC}(\mathrm{d})$ & - & $0.45(0.10)$ & $<0.001$ \\
\hline \multirow[t]{2}{*}{ CFI (d) } & 1 & $0.19(0.17)$ & 0.344 \\
\hline & 2 & $0.08(0.20)$ & 0.262 \\
\hline \multirow[t]{3}{*}{ CI (d) } & 1 & $0.14(0.22)$ & 0.200 \\
\hline & 2 & $0.21(0.25)$ & 0.033 \\
\hline & 3 & $0.53(0.29)$ & $<0.001$ \\
\hline \multirow[t]{2}{*}{$\mathrm{CE}-\mathrm{cow}$} & Heifers & $6.59(0.99)$ & $<0.001$ \\
\hline & Cows & $5.79(0.70)$ & $<0.001$ \\
\hline \multirow[t]{2}{*}{$\mathrm{CE}-$ calf } & Heifers & $-2.09(0.71)$ & 0.001 \\
\hline & Cows & $0.65(0.53)$ & 0.110 \\
\hline \multirow[t]{3}{*}{ SCS } & 1 & $4.25(2.63)$ & 0.053 \\
\hline & 2 & $3.20(2.83)$ & 0.129 \\
\hline & 3 & $8.69(3.37)$ & 0.005 \\
\hline
\end{tabular}

${ }^{1} \mathrm{MY}=$ milk yield $305-\mathrm{d} ; \mathrm{FY}=$ fat yield $305-\mathrm{d} ; \mathrm{PY}=$ protein yield $305-\mathrm{d}$; FSTC $=$ interval from first service to conception; $\mathrm{GL}=$ gestation length; $\mathrm{AFC}=$ age at first calving; $\mathrm{CFI}=$ interval from calving to first insemination; $\mathrm{CI}=$ calving interval; $\mathrm{CE}=$ calving ease.

${ }^{2}$ For CE-cow, inbreeding of the dam was fitted, and for CE-calf, inbreeding of the calf was fitted.

ing coefficients of 0 to $12.5 \%$ and 12.5 to $25 \%$ had 1 and $3 \%$ greater incidence of dystocia, respectively, over noninbred dams. Likewise, an increase in probability of calving difficulty in first-parity dams of 0.92 and $0.66 \%$ for males and females was observed because of the increased inbreeding in US Holsteins (Adamec et al., 2006).

Estimates of inbreeding depression on SCS were unfavorable and low in all parities, but only significant $(P<$ 0.01 ) for the third lactation, where SCS increased 8.69 $\times 10^{-3}$ units per $1 \%$ increase in inbreeding. Although the higher inbreeding depression for the latter lactation in the present study was in accordance with the results of Croquet et al. (2006) and Mc Parland et al. (2007), which documented a greater effect of inbreeding on SCS in older animals, no significant results were reported by Smith et al. (1998) and Thompson et al. (2000). Because SCS has a moderate to high genetic correlation with mastitis (Sørensen et al., 2009), this finding might indicate that inbred animals tend to be less resistant to mastitis (Sørensen et al., 2006).

The effects of inbreeding on 19 linear type traits are presented in Table 6 . The inbreeding depression for type traits were relatively small, ranging from $-89.60 \times 10^{-4}$ for body depth and size to $113.00 \times 10^{-4}$ for suspensory ligament. The effect of inbreeding was significant only for stature, chest width, body depth, size, rear udder height, suspensory ligament, udder depth, and front and rear teat placement. The negative inbreeding depression of $-36.90 \times 10^{-4},-84.70 \times 10^{-4},-89.60 \times$ $10^{-4}$, and $-89.60 \times 10^{-4}$ for stature, chest width, body depth, and size, respectively, indicated that inbred cows may be short, small, and narrow-chested with a shallow body depth compared with noninbred cows. Also, inbred cows tended to have high udder depth $\left(85.50 \times 10^{-4}\right)$ and high front $\left(68.10 \times 10^{-4}\right)$ and rear $\left(79.20 \times 10^{-4}\right)$ teat placement, which are not desirable because extremely deep or extremely shallow udders and extremely inside or extremely outside fore teat placement increase risk of involuntary culling. Because the average magnitude of udder depth and front teat placement are below their optimum (Table 2), no culling risk is expected to occur in these traits for the next few generations. In general, the unfavorable effects of inbreeding on some linear type traits in the present study were in close agreement with the results of Smith et al. (1998), Croquet et al. 
Table 6. Estimates of inbreeding depression and SE for $1 \%$ increase of inbreeding and their corresponding $P$-values for type traits (units $\times 10^{-4}$ )

\begin{tabular}{lrr}
\hline Trait & Inbreeding depression (SE) & $P$-value \\
\hline Stature & $-36.90(11.01)$ & $<0.001$ \\
Chest width & $-84.70(33.42)$ & 0.006 \\
Body depth & $-89.60(23.72)$ & $<0.001$ \\
Loin & $-27.50(34.28)$ & 0.211 \\
Size & $-89.60(23.72)$ & 0.003 \\
Rump length & $-73.30(64.04)$ & 0.425 \\
Pin set & $10.80(57.36)$ & 0.126 \\
Pin width & $-13.30(53.68)$ & 0.402 \\
Rear leg side view & $-18.70(27.68)$ & 0.250 \\
Foot angle & $-39.00(33.71)$ & 0.123 \\
Fore udder attachment & $8.87(49.91)$ & 0.429 \\
Rear udder height & $-153.00(78.29)$ & 0.025 \\
Rear udder width & $-89.40(71.06)$ & 0.104 \\
Suspensory ligament & $113.00(58.74)$ & 0.027 \\
Udder depth & $85.50(36.31)$ & 0.009 \\
Front teat placement & $68.10(36.64)$ & 0.032 \\
Rear teat placement & $79.20(45.73)$ & 0.041 \\
Teat length & $-6.33(29.15)$ & 0.414 \\
Angularity & $-22.90(23.27)$ & 0.162 \\
\hline
\end{tabular}

(2006), and Mc Parland et al. (2007), who reported that inbred animals were characterized as being smaller and shallower and that estimates of inbreeding depression for type traits tended to be negligible for all evaluated traits and nonsignificant for some.

Table 7 indicates the relative risk of involuntary culling by class of inbreeding coefficient. A relative culling risk $>1$ indicates a high culling risk at any time relative to the least inbred cows. In the present study, the relative risk of cows being culled for the classes of $12.50 \leq$ $F<18.75$ and $F \geq 18.75$ was 13.70 and $14.88 \%$ higher than in cows with extremely low inbreeding coefficients. The relationship between inbreeding and the relative risk of involuntary culling was similar to that in the few reported studies. Thompson et al. (2000) indicated a decrease in survival with increasing inbreeding in US Holsteins. In addition, a trend toward increased risk of culling among more inbred cows was observed in the study of Sewalem et al. (2006) for Canadian Holsteins.

\section{CONCLUSIONS}

The rate of inbreeding for Iranian Holsteins was 0.22 and $0.15 \%$ per year for females and males, respectively, from 1989 to 2007. This rate has been substantially higher in recent years (0.31 and $0.21 \%$ per year in females and males from 2000 to 2007). The large increase in inbreeding may be attributed to the high probability of uncontrolled matings among relative cows with a few importing semen from elite bulls. Overall, estimates of

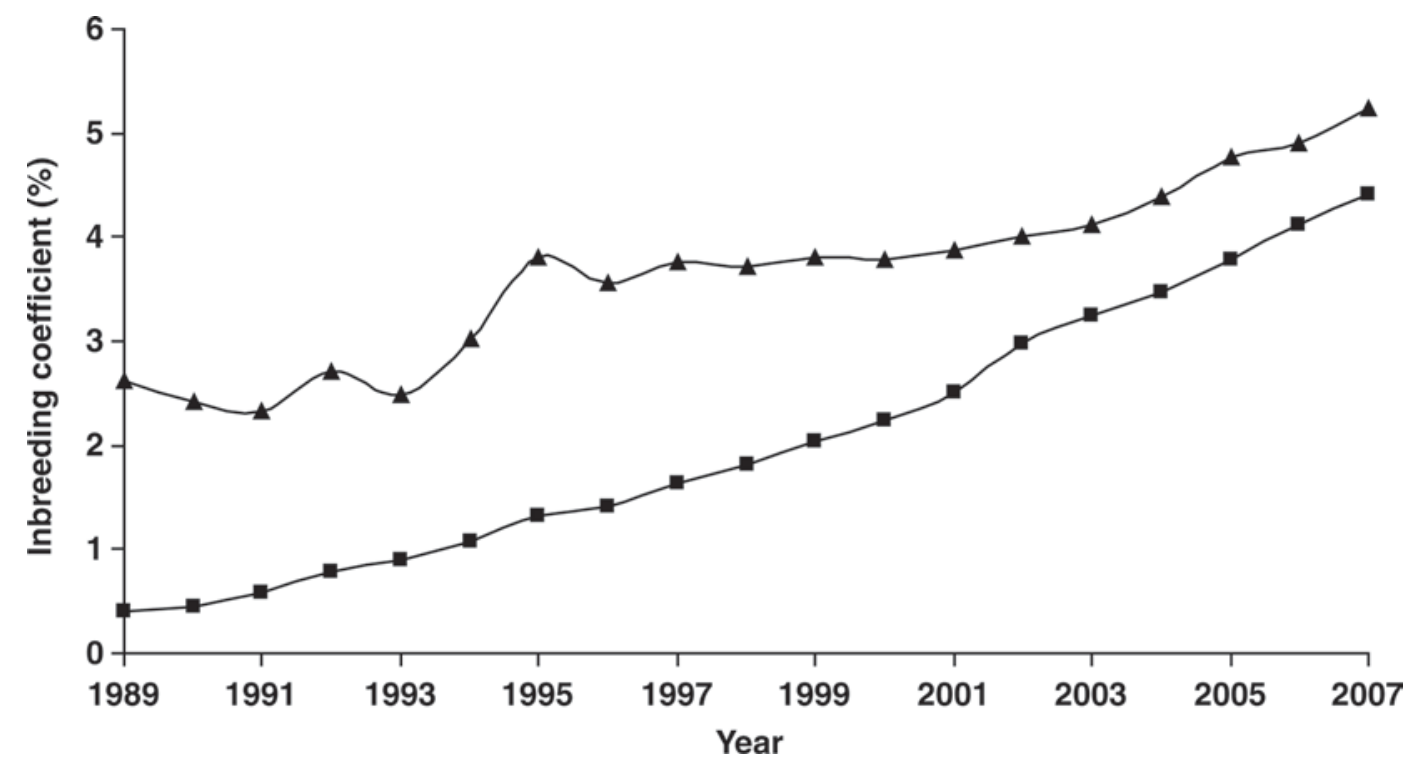

Figure 2. Average inbreeding coefficient within year of birth for males ( $\mathbf{\Delta})$ and females 
Table 7. Relative risk of culling by classes of inbreeding $(F)$

\begin{tabular}{lc}
\hline Inbreeding $(\%)$ & Relative risk of culling \\
\hline $0.000 \leq F<3.125$ & 1.0000 \\
$3.125 \leq F<6.250$ & 1.0044 \\
$6.250 \leq F<12.500$ & 1.0182 \\
$12.500 \leq F<18.750$ & 1.1367 \\
$F \geq 18.750$ & 1.1488 \\
\hline
\end{tabular}

inbreeding depression obtained from the present study were consistent with the results reported in the literature. The effect of inbreeding was significant for all production traits. No significant inbreeding depression appeared on reproductive traits except for CI, AFC, and CE. For SCS, unfavorable effect of inbreeding was observed only for third-parity cows. Also, the results indicated that inbred cows tended to have short and narrow conformation but more desirable udders and teats. The survival analysis indicated that there was a significantly negative relationship between inbreeding and longevity, resulting in an increased risk of culling among more inbred cows.

\section{ACKNOWLEDGMENTS}

The authors express their thanks to Per Madsen (Department of Genetics and Biotechnology, Faculty of Agricultural Sciences, Aarhus University, Tjele, Denmark) for providing DMU package and invaluable assistance throughout the study, and to Vincent Ducrocq (Département de Génétique Animale, INRA, Jouy en Josas, France) for providing the survival Kit software, Filippo Miglior (CDN, Ontario, Canada, and Agriculture and Agri-Food Canada, Ontario, Canada) and H. Jorjani (Interbull, Uppsala, Sweden) for help in obtaining Canadian and international pedigrees of sires. The data were generously provided by Animal Breeding Centre of Iran. The first author acknowledges financial support of the Tarbiat Modares University and the Ministry of Science, Research and Technology of the Islamic Republic of Iran.

\section{REFERENCES}

Adamec, V., B. G. Cassell, E. P. Smith, and R. E. Pearson. 2006. Effects of inbreeding in the dam on dystocia and stillbirths in US Holsteins. J. Dairy Sci. 89:307-314.

Ali, A. K. A., and G. E. Shook. 1980. An optimum transformation for somatic cell concentration in milk. J. Dairy Sci. 63:487-490.

Andersen-Ranberg, I. M., B. Heringstad, D. Gianola, Y. M. Chang, and G. Klemetsdal. 2005. Comparison between bivariate models for 56-day nonreturn and interval from calving to first insemination in Norwegian Red. J. Dairy Sci. 88:2190-2198.

Animal Improvement Programs Laboratory. 2009. Subject: Inbreeding. http://aipl.arsusda.gov Accessed Dec. 1, 2009.

Berg, P., J. Nielsen, and M. K. Sørensen. 2006. EVA: Realized and predicted optimal genetic contributions. Proc. 8th World Congr. Genet. Appl. Livest. Prod., CD-ROM Commun. 27-09.
Canadian Dairy Network. 2009. Subject: Inbreeding. http://www.cdn. ca Accessed Dec. 1, 2009.

Cassell, B. G. 2009. Inbreeding. Virginia Polytechnic Institute and State University. www.ext.vt.edu.

Cassell, B. G., V. Adamec, and R. E. Pearson. 2003. Effect of incomplete pedigrees on estimates of inbreeding and inbreeding depression for days to first service and summit milk yield in Holsteins and Jerseys. J. Dairy Sci. 86:2967-2976.

Croquet, C., P. Mayeres, A. Gillon, S. Vanderick, and N. Gengler. 2006. Inbreeding depression for global and partial economic indexes, production, type, and functional traits. J. Dairy Sci. 89:2257-2267

Ducrocq, V., and J. Sölkner. 1998a. Implementation of a routine breeding value valuation for longevity of dairy cows using survival analysis techniques. Proc. 6th World Congr. Genet. Appl. Livest. Prod., Armidale, Australia. 27:447-448.

Ducrocq, V., and J. Sölkner. 1998b. The Survival Kit-V3.0-A package for large analysis of survival data. Proc. 6th World Congr. Genet. Appl. Livest. Prod. 27:447-448.

Falconer, D. S. and T. F. C. Mackay. 1996. Introduction to Quantitative Genetics. 4th ed. Longman Scientific and Technical, Harlow, UK.

Faraji Arogh, H. 2009. Estimate of inbreeding coefficient of Iran Holsteins and its effect on milk production traits. MSc Thesis. Department of Animal Science, Tarbiat Modares University, Iran.

González-Recio, O., E. Lopez de Maturana, and J. P. Gutierrez. 2007. Inbreeding depression on female fertility and calving ease in Spanish dairy cattle. J. Dairy Sci. 90:5744-5752.

Jamrozik, J., J. Fatehi, G. J. Kistemaker, and L. R. Schaeffer. 2005. Estimates of genetic parameters for Canadian Holstein female reproduction traits. J. Dairy Sci. 88:2199-2208.

Kearney, J. F., E. Wall, B. Villanueva, and M. P. Coffey. 2004. Inbreeding trends and application of optimized selection in the UK Holstein population. J. Dairy Sci. 87:3503-3509.

MacCluer, J. W., A. J. Boyce, B. Dyke, L. R. Weitkamp, D. W. Pfennig, and C. J. Parsons. 1983. Inbreeding and pedigree structure in Standardbred horses. J. Hered. 74:394-399.

Madsen, P., and J. Jensen. 2007. A user's guide to DMU. A package for analysing multivariate mixed models. Version 6 , release 4.7 . Tjele, Denmark.

Mc Parland, S., J. F. Kearney, M. Rath, and D. P. Berry. 2007. Inbreeding effects on milk production, calving performance, fertility, and conformation in Irish Holstein-Friesians. J. Dairy Sci. 90:4411-4419.

Miglior, F., and E. B. Burnside. 1995. Inbreeding of Canadian Holstein cattle. J. Dairy Sci. 78:1163-1167.

Sewalem, A., G. J. Kistemaker, F. Miglior, and B. J. Van Doormaal. 2006. Analysis of inbreeding and its relationship with functional longevity in Canadian dairy cattle. J. Dairy Sci. 89:2210-2216.

Smith, L. A., B. G. Cassell, and R. E. Pearson. 1998. The effects of inbreeding on the lifetime performance of dairy cattle. J. Dairy Sci. 81:2729-2737.

Sørensen, A. C., P. Madsen, M. K. Sørensen, and P. Berg. 2006. Udder health shows inbreeding depression in Danish Holsteins. J. Dairy Sci. 89:4077-4082.

Sørensen, A. C., M. K. Sørensen, and P. Berg. 2005. Inbreeding in Danish dairy cattle breeds. J. Dairy Sci. 88:1865-1872.

Sørensen, L. P., T. Mark, P. Madsen, and M. S. Lund. 2009. Genetic correlations between pathogen-specific mastitis and somatic cell count in Danish Holsteins. J. Dairy Sci. 92:3457-3471.

Thompson, J. R., R. W. Everett, and N. L. Hammerschmidt. 2000. Effects of inbreeding on production and survival in Holsteins. J. Dairy Sci. 83:1856-1864.

Tohidi, R., R. Vaez Torshizi, M. Moradi Shahrbabak, and M. B. Sayyad Nejad. 2002. Inbreeding and its effects on milk and fat yields of Iran Holsteins. Proc. 7th World Congr. Genet. Appl. Livest. Prod., CD-ROM Commun. 01-55.

Wiggans, G. R., P. M. VanRaden, and J. Zuurbier. 1995. Calculation and use of inbreeding coefficients for genetic evaluation of United States dairy cattle. J. Dairy Sci. 78:1584-1590. 